DOI: https://doi.org/10.24144/2409-6857.2018.2(52).92-96

УДК 37.014.54: 330.354

Усик B.I.

\title{
ОСВІТА В ЗАБЕЗПЕЧЕННІ СТІЙКОГО ЕКОНОМІЧНОГО ЗРОСТАННЯ
}

\begin{abstract}
В статті аналізуються різні точки зору щуодо питання ролі освіти у забезпеченні економічного зростання. Результатом теоретичного аналізу сформульованій у статті проблеми є висновок про наявність а арсеналі сучасної макроекономіки достатнього інструментарію для доведення зв'язку між показниками сфери освіти та показниками економічного зростання. Прикладний результат дослідження полягає у встановленні певних закономірностей щодо впливу рівня освіти в краӥні на ї̈ економічний розвиток. Наступним етапом дослідження $є$ обгрунтування підходу до визначення зв'язку між екзогенними показниками сфери освіти, які пов'язані з ї̈ віковою структурою, фінансуванням та рівнем інноваційності та ендогенним показником - економічним зростанням.
\end{abstract}

Ключові слова: освіта, економічне зростання, фінансування освіти, людський капітал, економіка знань.

Постановка проблеми. Сучасні тенденції розвитку свідчать, що освіта та інвестиції в людські ресурси $є$ одним із пріоритетів національних стратегій та національних політик, економічного та технічного прогресу. Тенденції інвестування в людський капітал та знання ведуть до перегляду економічної теорії та моделей. Зв'язок між освітою та економічним зростанням лежить в так званій теорії людського капіталу, згідно якої освіта $є$ формою інвестицій, подібної до придбання нової машини чи устаткування, тобто подібною до інвестицій у фізичний капітал. Теорія людського капіталу не лише наголошує на тому, що роль людини у економічній системі суспільства має бути вирішальною, а й на необхідності інвестувати у виробничі можливості людини, тобто сприяти розвитку ії як працівника. Такими інвестиціями $є$ освітні витрати (формальна і неформальна освіта), професійна підготовка на виробництві тощо.

Але чи існує насправді зв'язок між витратами на освіту та економічним зростанням в країні? Чи має вплив збільшення частки людей з середньою та вищою освітою серед дорослого населення на темп економічного зростання?

Аналіз останніх досліджень і публікацій. Сучасна «традиційна виробнича функція», окрім таких факторів як праця, матеріали, капітал, енергія, включає знання, інвестиції в які можуть збільшити виробничу потужність більше, ніж будь-який інший фактор виробництва і перетворити їх у нові продукти та процеси, тобто стати ключем до довгострокового економічного зростання.

\footnotetext{
(0) Усик Віра Іванівна, к.е.н., доц., докторант кафедри національної економіки та публічного управління ДВНЗ «Київський національний економічний університет імені Вадима Гетьмана», м. Київ, e-mail: vivayoung70@gmail.com, тел. +380958986296
}

На користь припущення про зв'язок фінансування освіти з економічним зростанням, продуктивністю праці, рівнем інноваційності економіки тощо свідчать численні роботи сотень дослідників.

У 60-х роках ХХ століття було введено поняття «економіка знань» («інноваційна економіка», «інформаційне суспільство») Ф. Махлупом [1] для визначення типу економіки, для якого втілення знань у виробництво забезпечує значну частку економічного зростання. Д. Рікардо відзначав значну роль у суспільному розвитку освіти та вважав іï низький рівень однією 3 причин економічного відставання деяких країн [2]. Засновники «чиказької школи» людського капіталу Т. Шульц та Г. Беккер, вперше в історії економічної думки використали термін «людський капітал». Т. Шульц під людським капіталом розуміє «знання, навички та здібності людини, які сприяють зростанню продуктивної сили іiі праці» [3]. Оскільки «освіта являється однією 3 форм капіталу, то людським його називають через те, що вона стає частиною конкретної людини, а капіталом тому, що $\epsilon$ джерелом майбутніх задоволень потреб і доходів, або і того і іншого разом взятих». Г. Беккер, як один 3 фундаторів теорії людського капіталу уважав, що «людський капітал формується за рахунок інвестицій в людину, до яких можна віднести навчання, підготовку на виробництві та інше» [4]. Із середини $80-\mathrm{x}$ років минулого століття дослідження економічного зростання переживають новий етап, що почався 3 робіт П. Ромера, Р. Лукаса та Г.Менк'ю. [5-7]. На думку цих вчених, нові досягнення визначали довгостроковий тренд зростання всередині моделі, що було втілено через створення моделей ендогенного зростання, де освіті надавалася особлива роль. О. Грішнова зазначає, що велике значення на формування людського капіталу має 
освіта та професійне навчання, а людський капітал «сприяює зростанню продуктивності праці i завдяки цьому впливає на зростання доходів (заробітків) свого власника та національного доходу» [8].

Важливий теоретичний та емпіричний внесок в дослідження взаємозв'язку економічного зростання та державних витрат здійснив у 1863 р. німецький вчений Адольф Вагнер, який довів існування між ними позитивної кореляції та стверджував, що ріст ВВП супроводжується прискореним зростання державних витрат (так званий закон Вагнера)[9].

Вважаємо, що потребує подальшої розробки і тому $€$ предметом дискусій дослідження взаємозв'язку освіти та економічного зростання, особливо в Україні. Це потребує аналізу тих показників у сфері освіти, які здатні чинити вплив на економічне зростання, а також показників фінансування сфери освіти, що є незаперечною передумовою нагромадження інтелектуального потенціалу.

Формулювання цілей статті. Дане дослідження $\epsilon$ першим етапом у вирішенні проблеми обгрунтування підходу до визначення зв'язку між екзогенними показниками сфери освіти, які пов'язані 3 iї віковою структурою, фінансуванням та рівнем інноваційності та ендогенним показником - економічним зростанням. Метою даного етапу $\epsilon$ виявлення різних підходів до ролі освіти в забезпеченні економічного зростання та оцінка можливостей їх ефективного застосування.

Опис основного матеріалу дослідження. Людський капітал визнаний найціннішим ресурсом світу. Саме людський капітал, а не матеріальні засоби виробництва, $\epsilon$ фактором підвищення конкурентоспроможності та економічного зростання. I саме фінансування освіти $\epsilon$ незаперечною передумовою нагромадження інтелектуального потенціалу.

Про вагому роль освіти у суспільному прогресі свідчить наявність тісного кореляційного зв'язку між якістю освітніх систем, розвитком університетів світового класу та економічним зростанням країн. Держави, які визнали пріоритетність університетської освіти, змогли перейти до розбудови інноваційної економіки, що забезпечує їм високі конкурентні позиції на світових ринках. Навіть в умовах нещодавньої світової фінансово-економічної кризи ці країни не тільки не зменшили витрати на освіту та інноваційну діяльність, а навпаки, їх збільшили. До таких країн долучився останнім часом Китай, який стрімко розпочав розбудову національної інноваційної системи, основними суб'єктами якої мають стати університети світового класу [10, c. 42].

Володіння знаннями прирівнюється розвиненими країнами за значенням до стратегічних ресурсів, таких як запаси сировини, території, золотий запас, золотовалютний резерв [11].

Науковці пропонують розглядати впливу освіти на економічне зростання 3 точки зору окремого фактора виробництва, який взаємодіє 3 іншими факторами та як передумови "виробничого навчання" або "навчання на власному досвіді”.

Проведені науковцями дослідження в більшості випадків доводять, що роль освіти як фактора економічного зростання полягає у збільшенні як індивідуальної, так і суспільної продуктивності праці, тобто має значний вплив на економічне зростання. «Здобуток від освіти дитини набуває не лише дитина чи їі батьки, але й інші члени суспільства. Освіта Вашої дитини сприяє добробуту всього суспільства» [12]. Більш того, сама освітня галузь стає однією 3 провідних продуктивних галузей в економіці розвинених держав та сприяє їх конкурентоспроможності на світових ринках. За оцінками експертів, в країнах 3 найбільш розвиненою економікою в середньому 60\% приросту національного доходу визначається приростом знань і освіченістю суспільства [13].

В світовій практиці існує багато досліджень, які вказують на міцний зв'язок між витратами на освіту i рівнем національного доходу країни. Дехто каже, що це вказує на те, що освіта призводить до зростання. І це можливо. Однак, це може просто вказувати на те, що багаті країни можуть дозволити собі витрачати на освіту більше, тобто можливо рівень витрат на освіту залежить від ВВП, а не ВВП залежить від рівня витрат на освіту.

Перевірка гіпотези колективом авторів Sayantan Ghosh Dastidar, Sushil Mohan and Monojit Chatterji показала, що в таких країнах, як Сполучені Штати Америки, Пакистан, Танзанія, Замбія та Індії витрати на освіту позитивно впливають на економічне зростання [14]. Avina Sabah Idrees and Muhammad Wasif Siddiqi на основі панельного аналізу також показали, що існує позитивний зв'язок між зростанням витрат на освіту та економічним зростанням та, що інвестиції в освіту впливають на розвиток країн. Для свого аналізу вони відібрали такі країни як Великобританія, США, Канада, Німеччини, Франції, Італія, Японія, Пакистан, Індія, Китай, Туреччина, Росія, Польща та Південна Африка [15]. Abhijeet Chandra [16] доводить, що в Індіï 
бум індустрії програмного забезпечення у великій мірі пов'язаний з величезними інвестиціями у 1950-х і 1960-х pp. у сферу освіти, зокрема в галузі технічних наук. Gemmel [17] на основі зроблених розрахунків робить висновок, що при збільшенні на 1 відсотковий пункт темпу нарощення людського капіталу через підвищення рівня освіти ВВП на душу населення зросте на 5,9 відсоткових. Murphy, Schleifer and Vishny [18] зазначають, що при зростанні видатків на початкову школу на 1 відсотковий пункт відбудеться збільшенням темпів зростання ВВП на душу населення на 2,2 відсоткових пункти . Разом $з$ тим, Levine and Renelt наголошують, що збільшення на 1 відсотковий пункт витрат в середню освіту призведе до зростання темпів ВВП на душу населення на 2,5-3,7 відсоткових пункти [19] . Чисельні роботи Томіч 3. щодо пошуку зв'язку між освітою та економічним зростанням мають наступні висновки - у США та Японії існує позитивна кореляція між державними витратами на освіту та зростанням ВВП. У випадку з США зростання витрат на освіту на $1 \%$ призведе до зростання ВВП на 0,78 $\%$, а в Японії - на $0,81 \%$. В країнах $\mathrm{CC}$ таке зростання коливатиметься від 1,33\% до 1\% . Окрім того, була підмічена одна особливість, що найбільша вигода для країни виявляється при збільшенні витрат на середню освіту, що можна пояснити тим, що молодь після середньої освіти починає працювати в економіці або продовжує свою освіту [20,21].

Наше дослідження $28^{1}$ країн світу дало змогу виявити тісний кореляційний зв'язок між такими показниками як витрати на освіту на приріст ВВП на душу населення в більш, ніж 10 аналізованих У своїй роботі Михаць С.П наголошує, що «важливе значення при аналізі ефективності освітньої діяльності мають також екстерналії освіти, зокрема, зменшення бідності в суспільстві, покращення здоров'я населення, демократизація країнах, що дало основу для подальших досліджень суспільства, поліпшення навколишнього середовища, культурний розвиток, послаблення криміногенної ситуації тощо. Ми глибоко переконані, що сфера освіти має як прямий вплив на економічне зростання, так i опосередковане. Так, наприклад, освіта вважа-

\footnotetext{
${ }^{1} 1$. Австрія, 2.Бельгія, 3.Болгарія, 4.Велика Британія, 5.Данія, 6.Естонія, 7.Ірландія, 8.Іспанія, 9.Італія, 10.Кіпр, 11.Латвія, 12.Литва, 13.Мальта, 14.Нідерланди, 15.Німеччина, 16.Польща, 17.Португалія, 18.Румунія, 19.Словаччина, 20.Словенія, 21.Угорщина, 22 Фінляндія, 23.Франція, 24.Чехія, 25.Швеція, 26.США, 27.Японія, 28.Австралія
}

-ється ефективним засобом для підвищення рівня народжуваності, скорочує бідність, сприяє покращенню стану ринку праці, зменшує нерівномірність розподілу доходів населення; може збільшити поширення еко-свідомості та забезпечити навички для зелених інновацій; зменшує сприйняття корупції та рівень злочинності в країні; сприяє сплаті податків населенням. Отже, «видатки на освіту мають чітко виражену соціально-економічну сутність та інвестиційну природу, адже вони сприяють не лише розвитку наукової, інвестиційної та інноваційної діяльності, а також перетіканню людського та соціального капіталу в фінансовий у вигляді віддачі від інвестицій і синергетичних позитивних екстерналій в соціально-економічний розвиток» [23]. Бергер і Фішер [24] зазначають, що держави можуть створювати міцні основи для економічного успіху та спільного процвітання шляхом інвестування в освіту. Забезпечення розширеного доступу до якісної освіти не тільки розширюватиме економічні можливості для мешканців, але й, швидше за все, сприятиме зміцненню загальної державної економіки, аніж усе, що може зробити державний уряд.

Висновки i перспективи подальших досліджень. В арсеналі сучасної макроекономіки $\epsilon$ достатньо теоретичних та практичних напрацювань щодо доведення зв'язку між освітою та економічним зростанням. Окрім того, важливим $\epsilon$ дослідження впливу збільшення освітніх витрат на темп економічного зростання. Адже, зменшення державних витрат на освіту пов'язують зі зниженням іiї якості, що призведе до зниження рівня розвитку людського потенціалу. Низький рівень останнього буде сприяти зменшенню економічного зростання, що в свою чергу зробить неможливим збільшення витрат на освіту i т.д. Це ще раз доводить існування емпіричного зв'язку між ВВП та показниками розвитку сфери освіти (в тому числі державними витратами на освіту) в обох напрямках. Ми можемо зробити висновок, що рівень цього зв'язку відрізняється в країнах, які мають різний рівень розвитку, тобто вплив має i зворотну сторону. Але в той же час $є$ частина досліджень, які свідчать, що високий освітній рівень населення не забезпечує країні адекватних економічних вигід, на що впливає сукупність різноманітних інших факторів. Перевірка цих гіпотез стане наступним етапом подальших досліджень у даному напрямку на основі статистичних даних за 10 років в 28 країнах світу та в Україні зокрема. 


\section{СПИСОК ВИКОРИСТАНИХ ДЖЕРЕЛ}

1. Machlup, F. The Production and Distribution of Knowledge in the United States [Текст] / F. Machlup. - NJ.: Princeton, 1962. $-283 \mathrm{p}$.

2. Риккардо Д. Сочинения / Д. Риккардо. - М.: Соцэкгиз,1995. - Т. 1. - 365 с.

3. Schultz T. Investment in human capital / Theodore Schultz // American Economic Review. — 1961. — № 1. — P. $1-17$.

4. Becker G. S. Human Capital. N.Y. : Columbia University Press, 1964. - 187 p.

5. Romer P.M. Growth based on increasing returns due to specialization /P.M.Romer // American Economic Review. - 1987, May. - V. 77. - № 2. - P. 56-62.

6. Romer P.M. Increasing returns and long-run growth / P.M. Romer // Journal of Political Economy. - October, 1986. - V. 94. - P. 1002-1037.

7. Lucas R.E. On the mechanics of economic development / R.E. Lucas // Journal of Monetary Economics. - 1988, July. - Випуск 22, № 1. - Р. 3-42.

8. Грішнова О. А. Людський капітал: формування в системі освіти і професійної підготовки / О. А. Грішнова. - К : Знання, 2001. - 254c.

9. Боярко І. М. Державні видатки в економіці країни: монографія / І. М. Боярко, Н. А. Дехтяр, О.В. Дейнека. - Суми : Сумське видавництво ПВКП «Корпункт», 2013. -109 с.

10. Дослідницькі університети: світовий досвід та перспективи розвитку в Україні : монографія / [А. Ф. Павленко, Л. Л. Антонюк, Н. В. Василькова, Д. О. Ільницький та ін.] ; за заг. ред. д.е.н., проф. А. Ф. Павленка та д.е.н., проф. Л. Л. Антонюк. — К. : КНЕУ, 2014. — 350, [2] с.

11. Зарецька Л. М. Роль освіти в економічному розвитку / Л. М. Зарецька, О. А. Кулініч // Економічна стратегія і перспективи розвитку сфери торгівлі та послуг. - 2014. - Вип. 2. - С. 197-207. - Режим доступу: http://nbuv.gov.ua/UJRN/esprstp_2014_2_22

12. "The Role of Government in Education," by Milton Friedman. From Economics and the Public Interest, ed. Robert A. Solo, copyright by the Trustees of Rutgers College in New Jersey. Reprinted by permission of Rutgers University Press. - P.14

13. Прокопенко І. Ф. Вища освіта як чинник економічного зростання України: сучасний стан та перспективи розвитку / І. Ф. Прокопенко, О. В. Мельникова // Збірник наукових праць Харківського національного педагогічного університету імені Г. С. Сковороди. Економіка. - 2017. - Вип. 17. - С. 5-14. - Режим доступу: http://nbuv.gov.ua/UJRN/znpkhnpu_eko_2017_17_3

14. Sayantan, Ghosh, Dastidar et. al. Relationship between public education expenditures and economic growth: The case of India, 2013. - . - Access mode: http://repo.sire.ac.uk/bitstream/10943/435/1/SIRE-DP-2013_07.pdf

15. Idrees, Alvina, Sabah and Siddiiqi Muhammad Wasif."Does Public Education Expenditure Cause Economic Growth? Comparison of Developed and Developing Countries."Pakistan Journal of Commerce and Social Sciences, 7(1), 2013. - P.174-183.

16. Chandra, Abhijeet. Does Government Expenditure on Education Promote Economic Growth? An Econometric Analysis, Munich Personal RePEc, 2010 . - Access mode: http://mpra.ub.uni-muenchen.de/25480

17. Gemmell, N. Evaluating the impacts of human capital stocks and accumulation on economic growth: some new evidence. Oxford Bulletin of Economics and Statistics, 1996. - № 58. - P. 9-28.

18. Murphy, K., Shleifer, A. and Vishny, R. () The allocation of talent: Implications for growth.Quarterly Journal of Economics, 1991. - №106.- P.503-530

19. Levine, R. and Renelt, D. A sensitivity analysis of cross-country growth regressions.American Economic Review, 1992. - №82.- P.942-963

20. Tomić, Zoran. Analysis of the impact of public education expenditure on economic growth of European Union, USA and Japan // 7th International Conference «Science and higher education in function of sustainable development». - Business and Technical College of Vocation Studies, Užice, Serbia, 2014.

21. Zoran T. Analysis of the Impact of Public Education Expenditure on Economic Growth of European Union and BRICS. Economic analysis. 2015. №48 (1-2). - P. 19-38.

22. Михаць С. Критерії оцінки ролі освіти в економічному зростанні / С. Михаць // Молодь і ринок. - 2010. № 12. - С. 61-64. - Режим доступу: http://nbuv.gov.ua/UJRN/Mir_2010_12_16

23. Воронцова А. С. Фінансове забезпечення розвитку системи освіти впродовж усього життя : дис. канд. екон. наук : спец. 08.00.08 «Гроші, фінанси і кредит» / Анна Сергіївна Воронцова ; Сум.держ. ун-т. Суми,2018. $-272 \mathrm{c}$.

24. A Well Educated Workforce Is Key to State Prosperity By Noah Berger and Peter Fisher August 22, 2013. Access mode: http://schottfoundation.org/resources/well-educated-workforce-key-state-prosperity

\section{REFERENCES}

1. Machlup, F. (1962). The Production and Distribution of Knowledge in the United States. - NJ.: Princeton [in English].

2. Rykkardo, D. (1995). Sochynenyja [Compositions].M.: Socekghyz [In Russian]. 
3. Schultz, T. (1961). Investment in human capital. - American Economic Review [in English].

4. Becker, G. S. (1964). Human Capital. - N.Y.:Columbia University Press [in English].

5. Romer, P.M. (1987). Growth based on increasing returns due to specialization. - American Economic Review, 2 [in English].

6. Romer, P.M. (1986). Increasing returns and long-run growth. Journal of Political Economy, 94 [in English].

7. Lucas, R.E. (1988). On the mechanics of economic development. Journal of Monetary Economics, 22/1 [in English].

8. Ghrishnova, O. A. (2001). Ljuds'kij kapital: formuvannja v sistemi osviti i profesijnoï pidgotovki [Human Capital: Formation in the System of Education and Professional Training]. K : Znannja [in Ukrainian].

9. Bojarko, N. A. \& Dekhtjar, O. V. \& Dejneka, O. V. (2013). Derzhavni vidatki v ekonomici kraïni [State expenditures in the economy of country]. Monograph.Sumy:Sumsjke vydavnyctvo PVKP «Korpunkt» [in Ukrainian].

10. Pavlenko, A. F., \& Antonjuk, L. L, \& Vasyljkova, N. V., \& Iljnycjkyj, D. O. \& other. (2014). Doslidnic'ki universiteti: svitovij dosvid ta perspektivi rozvitku v Ukraïni [Research Universities: Global Experience and Development Prospects in Ukraine]. Monograph. K. : KNEU [in Ukrainian].

11. Zarecjka, L. M. \& Kulinich, O. A. (2014). Rol' osviti v ekonomichnomu rozvitku [The Role of Education in Economic Development]. Ekonomichna strateghija i perspektyvy rozvytku sfery torghivli ta poslugh - Economic strategy and prospects for the development of trade and services, 2, 197-207. Retrieved from http://nbuv.gov.ua/UJRN/esprstp_2014_2_22 [in Ukrainian].

12. Friedman M. (1955). «The Role of Government in Education». From Economics and the Public Interest, ed. Robert A. Solo, copyright by the Trustees of Rutgers College in New Jersey. Reprinted by permission of Rutgers University Press [in English].

13. Prokopenko, I. F., \& Meljnykova, O. V. (2017). Vishha osvita jak chinnik ekonomichnogo zrostannja Ukraïni: suchasnij stan ta perspektivi rozvitku [Higher education as a factor of Ukraine's economic growth: the current state and prospects of development]. Zbirnyk naukovykh pracj Kharkivsjkogho nacionaljnogho pedaghoghichnogho universytetu imeni Gh. S. Skovorody. Ekonomika - Collection of scientific works of the Kharkiv National Pedagogical University named after G. S. Skovoroda. Economy, 17, 5-14. Retrieved from http://nbuv.gov.ua/UJRN/znpkhnpu_eko_2017_17_3 [in Ukrainian].

14. Sayantan, Ghosh, Dastidar et. Al. (2013). Relationship between public education expenditures and economic growth. The case of India. Retrieved from http://repo.sire.ac.uk/bitstream/10943/435/1/SIRE-DP-2013_07.pdf [in English]

15. Idrees, Alvina, Sabah \& Siddiiqi Muhammad Wasif. (2013). "Does Public Education Expenditure Cause Economic Growth? Comparison of Developed and Developing Countries."Pakistan Journal of Commerce and Social Sciences, №7(1) [in English].

16. Chandra, Abhijeet (2010). Does Government Expenditure on Education Promote Economic Growth?. An Econometric Analysis, Munich Personal RePEc Archive. Retrieved from http://mpra.ub.uni-muenchen.de/25480 [in English]

17. Gemmell, N. (1996). Evaluating the impacts of human capital stocks and accumulation on economic growth: some new evidence. Oxford Bulletin of Economics and Statistics, 58 [in English].

18. Murphy, K., \& Shleifer, A. \& Vishny, R. (1991). The allocation of talent: Implications for growth.Quarterly Journal of Economics, 106 [in English]

19. Levine, R. and Renelt, D. (1992) A sensitivity analysis of cross-country growth regressions.American Economic Review, 82 [in English].

20. Tomić, Zoran. (2014). Analysis of the impact of public education expenditure on economic growth of European Union, USA and Japan. - 7th International Conference «Science and higher education in function of sustainable development». - Business and Technical College of Vocation Studies, Užice, Serbia [in English].

21. Zoran, T. (2015). Analysis of the Impact of Public Education Expenditure on Economic Growth of European Union and BRICS. Economic analysis, 48 (1-2) [in English].

22. Mykhacj, S. (2010). Kriterii ocinki roli osviti v ekonomichnomu zrostanni [Criteria for assessing the role of education in economic growth]. Molodj i rynok - Youth and market,12, 61-64. Retrieved from http://nbuv.gov.ua/UJRN/Mir_2010_12_16 [in Ukrainian].

23. Voroncova, A. S. (2018), Finansove zabezpechennja rozvitku sistemi osviti vprodovzh us'ogo zhittja [Financial support for the development of the education system throughout life] Candidate's thesis. Sumy. SumDU [in Ukrainian].

24. Berger, Noah \& Fisher, Peter. (2013). A Well Educated Workforce Is Key to State Prosperity. Retrieved from http://schottfoundation.org/resources/well-educated-workforce-key-state-prosperity [in English].

Одержано 14.09.2018 p. 